\title{
First record of Coenosia attenuata Stein, 1903 (Diptera: Muscidae) in Venezuela
}

Yohan Solano-Rojas ${ }^{1}$, Adrian Pont ${ }^{2}$, José De Freitas ${ }^{3}$, Gustavo Moros ${ }^{3} \&$ Yaritza Goyo ${ }^{1}$

1 Departamento de Ecología y Control de Calidad. Decanato de Agronomía. Universidad Centroccidental Lisandro Alvarado (UCLA). Lara. Venezuela.

2 Oxford University Museum of Natural History. Oxford. England.

3 Vivero Los Montes Verdes. Finca Monverana. Miranda. Venezuela.

\section{Correspondence}

Y. Solano-Rojas

E-mail: yohansolano@gmail.com

Received: 7 July 2017

Accepted: 17 November 2017

Published on-line: 13 December 2017

\section{Resumen}

Primer registro de Coenosia attenuata Stein, 1903 (Diptera: Muscidae) en Venezuela

La mosca tigra, Coenosia attenuata Stein, 1903 es un importante depredador de insectos pequeños como moscas blancas, moscas del mantillo, minadores, y otros pequeños hemípteros y lepidópteros. El objetivo de esta investigación es reportar la presencia de esta especie por primera vez en Venezuela, donde ha sido observada en casas de cultivo ubicadas en el estado Miranda, depredando adultos de Trialeurodes vaporariorum (Westwood, 1856) y de moscas de los géneros Bradysia Winnertz, 1867 y Liriomyza Mik, 1894 sobre crisantemo (Chrysanthemun sp.), gerbera (Gerbera jamesonii Bolus y Hook), lechuga (Lactuca sativa L.) y pimentón (Capsicum annuum L.). La presencia de la mosca tigra en Venezuela subraya la necesidad de investigaciones sobre su uso potencial como un agente de biocontrol de insectos plaga.

Palabras clave: Control biológico, Mosca tigre, Depredador.

\begin{abstract}
The tiger-fly Coenosia attenuata Stein, 1903 is an important predator of small insects such as whiteflies, fungus gnats, leafminers, and other small Hemiptera and Lepidopters. The aim of this research is to report the occurrence of this species for first time in Venezuela, where it has been observed in greenhouses located in Miranda state, predating adults of Trialeurodes vaporariorum (Westwood, 1856) and of the fly genera Bradysia Winnertz, 1867 and Liriomyza Mik, 1894 on chrysanthemum (Chrysanthemum sp.), gerbera (Gerbera jamesonii Bolus ex Hook), lettuce (Lactuca sativa L.) and pepper (Capsicum annuum L.). The occurrence of the tiger-fly in Venezuela underlines the necessity for researches into its potential use as a biocontrol agent of insect pests.
\end{abstract}

Key words: Biological control, Tiger-fly, Predator. 


\section{Introduction}

Coenosia attenuata Stein, 1903 (Diptera: Muscidae), known as the "tiger-fly" or "killer-fly", is a species described from Egypt and is now distributed in many countries of Europe, Africa, Asia and Oceania (Pont 1977, 1980, 1989, Couri \& Salas 2010, Pohl et al. 2012, Seabra et al. 2014). This fly has been shown to be an important natural enemy as both the larvae and the adults are predators. The adult is polyphagous and can catch and kill prey even when not hungry (Martinez \& Cocquempot 2000, Sensenbach 2004). As a result, various researches have been conducted to study the adaptability of $C$. attenuata to laboratory rearing in order to produce it in large numbers for release among commercial crops (Martins et al. 2012, 2015).

Tiger-fly adults are characterized by the manner in which they attack any potential prey that flies near them. The fly catches its prey in mid-air with its front legs and then takes it to a nearby surface where it uses its proboscis to make a hole in the neck area and to suck the body contents of the prey. Bodies can be found with a hole in the dorsal part of the occiput (towards the thorax) or decapitated (Mateus 2012, Martins et al. 2012). The characteristics of the attack have been studied by Mateus (2012) and Wardill et al. (2015) who have described how $C$. attenuata can move towards its prey when this is located at a distance of 7.9 to $30 \mathrm{~cm}$.

Among the species recorded as the prey of $C$. attenuata are the following: Bemisia tabaci (Gennadius, 1889) and Trialeurodes vaporariorum (Westwood, 1856) (Hemiptera: Aleyrodidae), Bactericera cockerelli Sulc, 1909 (Hemiptera: Triozidae), Bradysia spp. (Diptera: Sciaridae), Liriomyza spp. (Diptera: Agromyzidae) and Tuta absoluta (Meyrick, 1917) (Lepidoptera: Gelechi- idae), which are common on plants grown in greenhouses (Téllez \& Tapia 2005, Mateus 2012, Martins et al. 2012, Bautista-Martínez et al. 2017).

On the American continent, the tiger-fly was recorded for the first time in Ecuador (2002) in greenhouses and in the field in Peru (MartínezSánchez et al. 2002). Since then, C. attenuata has invaded different countries such as the United States (2002), Canada (2004), Argentina (2005), Colombia (2006), Costa Rica (2008), Chile (2010) and México (2017) where it has been reported feeding on the insect pests of crops grown in those regions (Hoebeke et al. 2003, Sensenbach 2004, Tellez \& Tapia 2005, Pérez 2006, Roy \& Fréchette 2006, Hernández 2008, Couri \& Salas 2010, Bautista-Martínez et al. 2017). This pattern of dispersal suggests that the tiger-fly is also present in other countries of South America because of its ability to adapt to different climatic conditions and to spread through the export of vegetable material (Martínez-Sánchez et al. 2002, Hernández 2008). According to Carvalho et al. (2005), 39 species of Coenosia Meigen, 1826 are recorded from the Neotropical region, and to date the only other species of this genus known from Venezuela is Coenosia plumiseta Stein, 1911 (Cova-García 1964).

\section{Description of Coenosia attenuata}

The fly is small, about $2.5-4.0 \mathrm{~mm}$ in length. The male has yellow antennae and legs (Fig. 1B), and the face and frons are strikingly silvery-white. The female is slightly larger and darker than the male, has black antennae, the femora largely black, and the abdomen with distinct black bands (which are absent in the male) (Fig. 1A). The female frons is brownish, contrasting with the golden colour of the ocellar triangle (Martinez \& Cocquempot 2000, Couri \& Salas 2010).
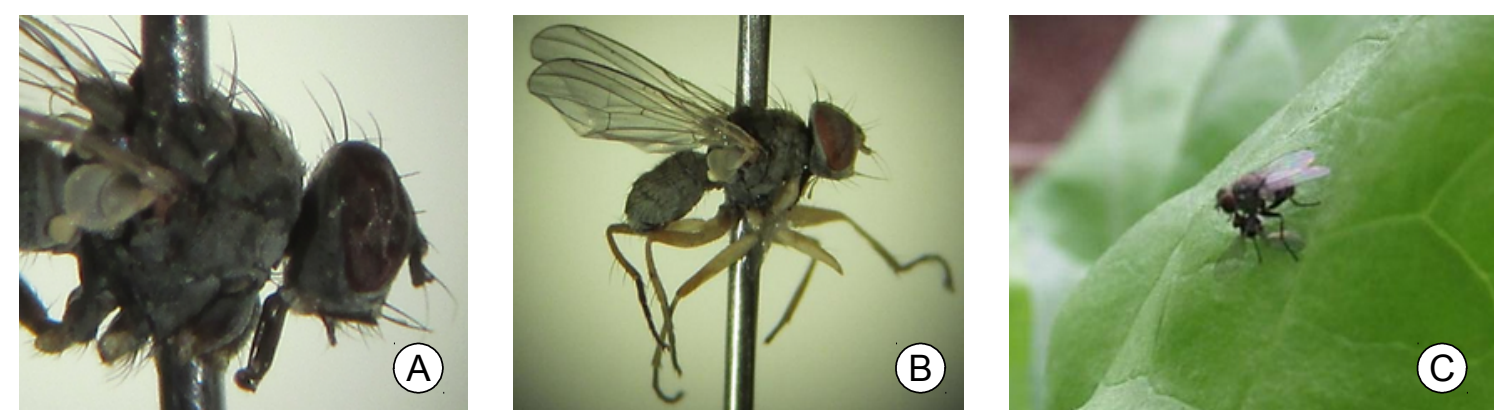

Figura 1. Coenosia attenuata. A: Probóscide de la hembra; B: Macho, lateral; C: Adulto depredando a Liriomyza sp.

Figure 1. Coenosia attenuata. A: Female proboscis; B: Male, lateral; C: Adult predating Liriomyza sp. 


\section{Results}

Adults of $C$. attenuata were collected feeding on whiteflies ( $T$. vaporariorum) and adults of Bradysia and Liriomyza (Fig. 1C), on chrysanthemum (Chrysanthemum sp., Asteraceae), gerbera (Gerbera jamesonii Bolus ex Hook, Asteraceae), lettuce (Lactuca sativa L., Asteraceae) and pepper (Capsicum annuum L., Solanaceae) which were grown in greenhouses in El Jarillo (Guaicaipuro municipality, Miranda state-Capital Region) at $1550 \mathrm{~m}$. This is the first report of $C$. attenuata in Venezuela, and its entry may have been in gerbera plants from Holland or Russia or through a natural entry from Colombia.

The presence of a large number of tiger-flies feeding on Bradysia and Liriomyza on crops grown in the Capital Region, suggests that this predator has the potential to control other insect pests such as whiteflies, fungus gnats, leafminers, and other small Hemiptera and Lepidopters, not only those associated with greenhouses but also in open field on crops such as tomato (Lycopersicon esculentum Mill.), onion (Allium cepa L.) and potato (Solanum tuberosum L.), grown in other regions of Venezuela.

Material examined: El Jarillo, Miranda. Venezuela. (1550 msnm) (10²1'01' 'N, 6702'20'’ W), 23-II-2016 (Y. Solano \& Y. Goyo): 2f, 1m. Specimens deposited in the Museo José M. Osorio. UCLA (Venezuela), with $1 \mathrm{~m}$ 1f in the Natural History Museum, London, United Kingdom.

\section{Acknowledgements}

We would like to express our thanks to the Fondo Nacional de Ciencia, Tecnología e Innovación (FONACIT) for funding project 2013002127, and to Lcda. Milagros Parra, CDCHT-UCLA project 022-AG-2013, Ing. Walter Morillo (INSUBIOL) and Ing. Raquel Chico for their assistance in carrying out this project.

\section{References}

Bautista-Martínez N, Illescas-Riquelme CP \& GarcíaÁvila CJ. 2017. First report of "hunter-fly" Coenosia attenuata (Diptera: Muscidae) in Mexico. Florida Entomologist 100(1): 174-175.

Carvalho CJB, Couri MS, Pont AC, Pamplona D \& Lopes SM. 2005. A catalogue of the Muscidae (Diptera) of Neotropical Region Zootaxa 860: 1-282.

Couri MS \& Salas C. 2010. First record of Coenosia at- tenuata Stein (Diptera: Muscidae) from Chile with biological notes. Revista Brasileira de Entomología 54(1): 144-145.

Cova-García P. 1964. Moscas de Venezuela. División de Endemias Rurales, Dirección de Malariología y Saneamiento ambiental, Ministerio de Sanidad y Asistencia Social Eds. Caracas, Venezuela. pp 50.

Hernández JR. 2008. Presencia de la mosca tigre en Costa Rica. Actualidad Fitosanitaria 33: 3.

Hoebeke ER, Sensenbach EJ, Sanderson JP \& Wraight SP. 2003. First report of Coenosia attenuata Stein (Diptera: Muscidae), an old world "Hunter Fly" in North America. Proceedings of the Entomological Society of Washington 105: 769-775

Martinez M \& Cocquempot C. 2000. La mouche Coenosia attenuata, nouvel auxiliaire prometteur en culture protégée. Revue Horticole 414: 50-52.

Martínez-Sánchez A, Marcos García MA \& Pont AC. 2002. Coenosia attenuata Stein 1903 (Diptera: Muscidae) nueva especie para la fauna neotropical. Bollettino di Zoología Agraria edi Bachicoltura 34: 269272.

Martins J, Domingos C, Nunes R, García A, Ramos C, Mateus C \& Figueiredo E. 2012. Coenosia attenuata (Diptera: Muscidae): Um predator em estudo para utilização em culturas protegidas. Revista de Ciências Agrárias 35(23): 229-235.

Martins J, Mateus C, Ramos AC \& Figueiredo E. 2015. An optimized method for mass rearing the tiger-fly, Coenosia attenuata (Diptera: Muscidae). European Journal of Entomology 112(3): 1-7.

Mateus C. 2012. Bioecology and behaviour of Coenosia attenuata in greenhouse vegetable crops in the Oeste region, Portugal. Bulletin of Insectology 65(2): 257-263.

Pérez MM. 2006. Estudio de la morfología externa de los adultos de la mosca cazadora Coenosia attenuata Stein, 1903 (Diptera: Muscidae) y primer reporte para Colombia. Revista de la Facultad de Ciencias Básicas 2: 67-87.

Pohl D, Kühne S, Karaca I \& Moll E. 2012. Review of Coenosia attenuata Stein and its first record as a predator of important greenhouse pests in Turkey. Phytoparasitica 40(1): 63-68.

Pont AC. 1977. Family Muscidae. In A Catalog of the Diptera of the Oriental Region. Volume 3. Suborder Cyclorrhapha (excluding Division Aschiza) (Delfinado MD, Hardy DE, eds). University of Hawaii, Honolulu. pp. 451-523

Pont AC. 1980. Family Muscidae. In Catalogue of the Diptera of the Afrotropical Region (Crosskey RW, ed.). British Museum (Natural History), London. pp. 721-761.

Pont AC. 1989. Family Muscidae. In Catalog of the Diptera of the Australasian and Oceanian Regions. Special Publications of the Bernice Pauahi Bishop Museum (Evenhuis NL, ed.). Bishop Museum Press, Honolulu. pp. 675-699.

Roy M \& Fréchette M. 2006. Première mention de Coenosia attenuata (Diptera: Muscidae) dans les serres au Québec. Laboratorie de diagnostic en phytoprotection. Ministère de l'Agriculture, des 
Pêcheries et de l'Alimentation, Quebec, Canada.

Seabra SG, Brás PG, Martins J, Martins R, Wyatt N, Shirazi J, Rebelo MT, Franco JC, Mateus C, Figueiredo E \& Paulo OS. 2014. Phylogeographical patterns in Coenosia attenuata (Diptera: Muscidae): a widespread predator on insect species associated with greenhouse crops. Biological Journal of the Linnean Society 114: 308-326.

Sensenbach EJ. 2004. Coenosia attenuata Stein (Diptera: Muscidae): a predatory fly in North American greenhouses. Master's Thesis. Cornell Univer- sity, Ithaca, New York.

Téllez Navarro MM \& Tapia Pérez E. 2005. Distribución y presencia de Coenosia attenuata (Diptera: Muscidae) en las principales zonas invernadas de la provincia de Almeria. Boletín de Sanidad Vegetal. Plagas 31: 335-341.

Wardill TJ, Knowles K, Barlow L, Tapia G, Nordström, Olberg RM \& González-Bellido PT. 2015. The killer fly hunger games: Target size and speed predict decision to pursuit. Brain, Behavior and Evolution 86(1): 28-37. 